\title{
ER-X: A Novel, Plasma Membrane-Associated, Putative Estrogen Receptor That Is Regulated during Development and after Ischemic Brain Injury
}

\author{
C. Dominique Toran-Allerand, ${ }^{1,3,5,6}$ Xiaoping Guan, ${ }^{2,6}$ Neil J. MacLusky,, ${ }^{2,6}$ Tamas L. Horvath, ${ }^{7}$ Sabrina Diano, ${ }^{7}$ \\ Meharvan Singh, ${ }^{2,6}$ E. Sander Connolly Jr, ${ }^{4}$ Imam S. Nethrapalli, ${ }^{2,6 *}$ and Alexander A. Tinnikov ${ }^{2,6 *}$ \\ Departments of ${ }^{1}$ Anatomy and Cell Biology, ${ }^{2}$ Obstetrics and Gynecology, ${ }^{3}$ Neurology, and ${ }^{4}$ Neurosurgery, and Centers for \\ 5 Neurobiology and Behavior and ${ }^{6}$ Reproductive Sciences, Columbia University College of Physicians and Surgeons, New \\ York, New York 10032, and 'Department of Obstetrics and Gynecology, Yale University School of Medicine, New Haven, \\ Connecticut 06510
}

\begin{abstract}
We showed previously in neocortical explants, derived from developing wild-type and estrogen receptor (ER)- $\alpha$ genedisrupted (ERKO) mice, that both $17 \alpha$ - and $17 \beta$-estradiol elicit the rapid and sustained phosphorylation and activation of the mitogen-activated protein kinase (MAPK) isoforms, the extracellular signal-regulated kinases ERK1 and ERK2. We proposed that the ER mediating activation of the MAPK cascade, a signaling pathway important for cell division, neuronal differentiation, and neuronal survival in the developing brain, is neither ER- $\alpha$ nor ER- $\beta$ but a novel, plasma membrane-associated, putative ER with unique properties. The data presented here provide further evidence that points strongly to the existence of a high-affinity, saturable, ${ }^{3} \mathrm{H}$-estradiol binding site $\left(K_{\mathrm{d}}, \sim 1.6 \mathrm{~nm}\right)$ in the plasma membrane. Unlike neocortical ER- $\alpha$, which is intranuclear and developmentally regulated, and neocortical ER- $\beta$, which is intranuclear and expressed throughout life, this
\end{abstract}

functional, plasma membrane-associated ER, which we have designated "ER-X," is enriched in caveolar-like microdomains (CLMs) of postnatal, but not adult, wild-type and ERKO neocortical and uterine plasma membranes. We show further that $\mathrm{ER}-\mathrm{X}$ is functionally distinct from $\mathrm{ER}-\alpha$ and $\mathrm{ER}-\beta$, and that, like $E R-\alpha$, it is re-expressed in the adult brain, after ischemic stroke injury. We also confirmed in a cell-free system that ER- $\alpha$ is an inhibitory regulator of ERK activation, as we showed previously in neocortical cultures. Association with CLM complexes positions ER-X uniquely to interact rapidly with kinases of the MAPK cascade and other signaling pathways, providing a novel mechanism for mediation of the influences of estrogen on neuronal differentiation, survival, and plasticity.

Key words: caveolae/caveolar-like microdomains; $17 \alpha$-estradiol; 17 $\beta$-estradiol; ERK1/2; ERKO; brain; neocortex; uterus; development
Two mammalian estrogen receptor (ER) genes are now known, encoding, respectively, ER- $\alpha(\sim 67 \mathrm{kDa})$ (White et al., 1987), which mediates many of the known transcriptional actions of estrogen in the brain, and the more recently cloned ER- $\beta$ (Kuiper et al., 1996) (60 kDa in mouse ovary) (Fitzpatrick et al., 1999), whose neural role is less well defined. A third, more distantly related member of the ER family, ER- $\gamma$, was recently cloned in teleosts only (Hawkins et al., 2000). ER- $\alpha$ and ER- $\beta$ appear to be

Received Nov. 21, 2002; revised July 16, 2002; accepted July 16, 2002.

This work was funded in part by National Institutes of Health (National Institute on Aging), National Institute of Mental Health, National Science Foundation, the Alzheimer's Association (Burks B. Lapham grant and T.L.L. Temple Foundation Discovery Award), and an Alcohol, Drug Abuse, and Mental Health Administration Research Scientist Award (all to C. D. T-A). We thank R. G. Anderson (University of Texas Southwestern) for helpful suggestions, T. M. Jessell (Columbia University) for constructive comments on previous versions of this manuscript, D. B. Lubahn (University of Missouri-Columbia) for the generous gift of heterozygote breeding pairs to found the ERKO mouse breeding colony, C. A Mason and H. H. Melikyan (Columbia University) for the gift of adult and P7 wild-type C57BL/6J mice, R. B. Hochberg (Yale University) and J. Katzenellenbogen (University of Illinois, Champaign/Urbana) for the gifts of $16 \alpha$-iodo $17 \beta$-estradiol and propylpyrazole triol (PPT), respectively, I. S. Edelman (Columbia University) for providing valuable discussions, and N. Nair and I. Laufer (Columbia University) for providing infarcted and noninfarcted neocortex.

*I.S.N. and A.A.T. contributed equally to this work.

Correspondence should be addressed to Dr. C. Dominique Toran-Allerand, Department of Anatomy and Cell Biology, 650 West 168th Street, Room BB1615, Columbia University College of Physicians and Surgeons, New York, NY 10032. E-mail: cdt2@columbia.edu.

Copyright $\odot 2002$ Society for Neuroscience $0270-6474 / 02 / 228391-11 \$ 15.00 / 0$ complementary but not redundant. Under steady-state conditions they are predominantly intranuclear and differ with respect to the homology of their functional domains, binding affinities, and ligand specificities (Kuiper et al., 1997). ER- $\alpha$ and ER- $\beta$ act as ligand-inducible transcriptional enhancers (Landers and Spelsberg, 1992; Beato and Klug, 2000), binding to cognate estrogen response elements (EREs) in DNA to regulate gene expression. Their spatiotemporal expression and distribution differ with developmental stage. Thus, although neocortical ER- $\beta$ is present throughout life (Shughrue et al., 1997), neocortical ER- $\alpha$ expression is developmentally regulated and normally expressed at high levels only during neocortical differentiation (Shughrue et al., 1990, 1997), suggesting a more restricted developmental role.

Some responses to estradiol cannot be attributed to ER- $\alpha$ or ER- $\beta$ (Singh et al., 1999, 2000), such as the ability of estrogen to regulate non-ERE-containing genes (Sukovich et al., 1994) and the very rapid (seconds to minutes) effects of estrogen (Kelly et al., 1978; Chiaia et al., 1983; Garcia-Segura et al., 1987; Migliaccio et al., 1993). Whereas such rapid responses appear inconsistent with direct transcriptional modulation via intranuclear receptors, they could be explained by the presence of plasma membraneassociated ERs that may be coupled to signal transduction pathways, typically associated with rapid activation by growth factors.

Neurotrophin activation of the mitogen-activated protein kinase (MAPK) cascade is mediated by cognate transmembrane receptors associated with caveolar-like microdomains (CLMs) of 
neuronal plasma membranes, the neuronal homologs of caveolae found in most cell types other than neurons (Huang et al., 1999). Caveolae/CLMs form important signaling modules that compartmentalize, modulate, and integrate growth factor-induced signaling events at the cell surface (Anderson, 1998; Okamoto et al., 1998). Like the neurotrophins, estrogen is an important neural trophic factor throughout life, with influences on neuronal differentiation (Toran-Allerand, 1976, 1980), survival (Green and Simpkins, 2000; Garcia-Segura et al., 2001), and plasticity (Matsumoto and Arai, 1981). 17 $\beta$-estradiol activates many signaling kinases, including protein kinase C (PKC) (G. Sétáló, Jr. and C. D. Toran-Allerand, unpublished observations), c-src (Nethrapalli et al., 2001), and members of the MAPK cascade (Watters et al., 1997; Singh et al., 1999, 2000). Rapid and sustained activation of cytoplasmic ERK1/2 is followed by nuclear translocation of phosphorylated ERK (Sétáló et al., 2001). We have proposed (Singh et al., 1999, 2000) that the ER mediating estrogen-induced activation of ERK1/2 in the developing brain is neither ER- $\alpha$ nor ER- $\beta$ and have hypothesized that, like neurotrophin receptors, this ER might be associated with CLMs (Toran-Allerand, 2000). Here we provide evidence for the existence of a novel and unique, plasma membrane-associated (CLM-associated) putative ER that we have designated "ER-X" (Toran-Allerand, 2000).

\section{MATERIALS AND METHODS}

All animal experiments were conducted in a humane manner, and animals were maintained according to protocols approved by the Institutional Animal Care and Use Committee at Columbia University. To identify and characterize ER-X, we analyzed, by immunoprecipitation, Western blotting and both light and electron microscopy, cell lysates, detergent-free, highly purified CLM preparations (Smart et al., 1995), plasma membranes, postnuclear supernatants (PNS), and tissue sections obtained from postnatal day 7 (P7) and adult wild-type and ER- $\alpha$ gene-disrupted (ERKO) neocortex and uterus.

Mice. Wild-type and ERKO mice were obtained from our breeding colony from matings of C57BL/6J $\times 129$ mice heterozygous $(+/-)$ for the ER- $\alpha$ gene disruption (Lubahn et al., 1993) and identified by genotyping (Singh et al., 2000) as either wild-type $(+/+)$ or homozygous $(-/-)$ for the disruption.

Genotyping. Tail snips were obtained from P3-P4 pups and used for genotyping, as previously described (Singh et al., 2000). Briefly, tissues were digested with Proteinase $\mathrm{K}$ at $56^{\circ} \mathrm{C}$ for $90 \mathrm{~min}$, followed by a $99^{\circ} \mathrm{C}$ incubation for $10 \mathrm{~min}$. The samples were then vortexed vigorously, and insoluble material was pelleted in a microfuge. Supernatants were used in a PCR reaction that used one primer pair [primer 1: 5'-CGG TCT ACG GCC AGT CGG GCA TC-3'; primer 2: 5'-GTA GAA GGC GGG AGG GCC GGT GTC-3'] for the ER- $\alpha$ gene product (product size, 239 $\mathrm{bp}$ ), and one primer pair [primer 2 from above with NEO Primer: 5'-GCT GAC CGC TTC CTC GTG CTT TAC-3'] for the neomycin insert-containing gene product (product size, $790 \mathrm{bp}$ ). The PCR program was performed as follows: 1 cycle at $94^{\circ} \mathrm{C}$ for $3 \mathrm{~min}, 30$ cycles of $94^{\circ} \mathrm{C}$ for $45 \mathrm{sec}, 62^{\circ} \mathrm{C}$ for $1 \mathrm{~min}$, and $72^{\circ} \mathrm{C}$ for $1 \mathrm{~min} 40 \mathrm{sec}$, followed by a final extension cycle of $72^{\circ} \mathrm{C}$ for $7 \mathrm{~min}$. Products were analyzed by agarose gel electrophoresis. Wild-type animals revealed the smaller 239 bp band, homozygous knock-outs (ERKO) showed the larger 790 bp band, and heterozygotes displayed both bands.

Neocortical cultures. Organotypic explant cultures, obtained from 360 $\mu \mathrm{m}$ hemicoronal slices of the frontal and cingulate neocortex of P2 wild-type and ERKO mice (day of birth = P1), were explanted onto collagen-coated, poly-D-lysine precoated coverslips and maintained in roller tube culture with gonadal steroid-deficient (gelding serum) and phenol red-free nutrient medium, as previously described (Singh et al., 1999, 2000). The nutrient medium was supplemented with $17 \beta$-estradiol ( $2 \mathrm{~nm}$; Sigma, St. Louis, MO) for 1 week, to optimize the development of CNS cultures from estrogen target regions (C. D. Toran-Allerand, unpublished observations).

Immunoprecipitation and Western blot analysis. Tissues were harvested into protease and phosphatase inhibitor-containing lysis buffer $(50 \mathrm{mM}$ Tris-base, $\mathrm{pH} 7.4,150 \mathrm{~mm} \mathrm{NaCl}, 10 \%$ glycerol, $1 \mathrm{~mm}$ EGTA, $1 \mathrm{~mm}$ $\mathrm{Na}_{3} \mathrm{VO}_{4}, 5 \mu \mathrm{M} \mathrm{ZnCl}, 100 \mathrm{~mm} \mathrm{NaF}, 10 \mu \mathrm{g} / \mathrm{ml}$ aprotinin, $1 \mu \mathrm{g} / \mathrm{ml}$ leupeptin, $1 \mathrm{~mm}$ PMSF, and 1\% Triton X-100) and prepared for immunoprecipitation and polyacrylamide gel electrophoresis, as previously described (Singh et al., 1999, 2000). Immunoprecipitation was performed, using an indirect technique with magnetic Dynabead separation (Dynal ASA, Oslo, Norway). All procedures were performed at $4^{\circ} \mathrm{C}$. In brief, P7 wild-type and ERKO cerebral cortices were homogenized by passing the sample eight times through a syringe fitted with a 20 -gauge needle. The homogenate was centrifuged at $100,000 \times g$ at $4^{\circ} \mathrm{C}$ for 15 min, and the protein concentration of the supernatant was determined (Lowry's method; Bio-Rad Detergent Compatible Protein Assay kit; Bio-Rad, Hercules, CA). For coimmunoprecipitation experiments, detergent was omitted from the lysis buffer. Depending on the species of the antibodies to be used, the clarified lysates were precleared with either anti-mouse or anti rabbit IgG-coated Dynabeads to reduce nonspecific antibody-antigen binding. For immunoprecipitation of ER-X, the precleared lysates, recovered from the supernatant, were then incubated at $4^{\circ} \mathrm{C}$ for $12-24 \mathrm{hr}$ with gentle shaking on a Nutator with $6 \mathrm{~F} 11$, a mouse monoclonal ER antibody raised against the full-length mouse ER- $\alpha$ molecule, which has proven to be optimal for immunoprecipitation of ER-X (Novocastra; Vector Laboratories, Burlingame, CA; 1:50-1:100). Primary antibody incubation was followed by the addition of anti-mouse IgG-coated Dynabeads for $3 \mathrm{hr}$ to capture and precipitate the antibodyantigen complexes. The ER antibodies and coimmunoprecipitated proteins were separated from the Dynabeads by the addition of $1 \times$ sample loading buffer, containing 5\% $\beta$-mercaptoethanol, and boiling for $5 \mathrm{~min}$. The Dynabeads were removed from the supernatant, using Dynal Magnetic Particle concentrators. The immunoprecipitated proteins were boiled at $95-100^{\circ} \mathrm{C}$ for $5 \mathrm{~min}$, and $300-500 \mu \mathrm{g}$ samples were loaded onto $10 \%$ SDS-PAGE gels and separated based on molecular size. Prestained rainbow markers (Bio-Rad) were used as molecular mass standards. The gels were then electroblotted onto polyvinylidene difluoride (PVDF) membranes.

Immunodetection of the protein of interest was performed by first blocking the membrane in 5\% nonfat dry milk (Carnation; Nestle USA) in TBS-Tween $20(10 \mathrm{~mm}$ Tris-base, $150 \mathrm{~mm} \mathrm{NaCl}$, and $0.2 \%$ Tween 20 , $\mathrm{pH}$ 8.0), followed by addition of the primary antibody. Wherever feasible, the PVDF membranes were probed with antibodies different from those used for immunoprecipitation to maximize the specificity of the immunoreactive product obtained. For ER-X in particular, we used either of two antibodies highly specific for ER- $\alpha$ : one specific for the ligand binding domain (LBD) of ER- $\alpha$ (MC20; 1:500; Santa Cruz Biotechnology, Santa Cruz, CA) and the other raised against amino acids 586-600 of the C terminus of ER- $\alpha$ (C1355; 1:2000; Friend et al., 1997; Upstate Biotechnology, Lake Placid, NY). Both antibodies recognize ER-X on Western immunoblots and by immunohistochemistry, but $\mathrm{C} 1355$ is not effective for immunoprecipitation. ER- $\beta$ was identified with antibodies directed against the LBD of ER- $\beta$ (1:250; Zymed, South San Francisco, CA). Negative controls to test for the specificity of the interactions were run in parallel and were performed by immunoprecipitation of the precleared protein lysates with preimmune mouse IgG and subsequently probed with the appropriate antibody. Additionally, a control peptide or lysate (uterus, ovary) was always used as a positive control to verify the identity of the band in the experimental lanes. The specificity of the signal was determined by the apparent molecular weight (MW) of the protein detected.

Antibody binding to protein was detected, using a secondary antibody conjugated to horseradish peroxidase (1:40,000; Pierce, Rockford, IL), and visualized autoradiographically on film, using enzyme-linked chemiluminescence (ECL; Amersham Biosciences, Arlington Heights, IL), as previously described (Singh et al., 1999, 2000). All blots were stripped and reprobed with the appropriate antibody to verify equal loading of protein across lanes and were analyzed densitometrically. For studies of ERK phosphorylation, the blots were first probed with phosphospecific ERK antibodies to detect phospho-ERK1/2 [phospho-p44/42 MAP Kinase (Thr202/Tyr204) (1:1000; Cell Signaling, Beverly, MA)]. The same blot was reprobed for total (nonphosphorylated) ERK protein to verify equal loading [ERK-1 (C-16), or ERK-2 (C-14)] (1:1000; Santa Cruz Biotechnology). All antibodies were diluted in the blocking solution.

Densitometric analyses. Densitometric analyses of ERK protein levels were performed to ensure similar levels of protein loaded across lanes. Autoradiograms were scanned in triplicate, using an HP Scanjet 6200C (Hewlett Packard Company, Greeley, CO) and analyzed using Kodak 1D Image Analysis Software (Eastman Kodak, Rochester NY). Net intensity values were calculated by subtracting the background within the area measured for each band from the total intensity within this same 
measured area to account for any variation in background intensity across the film.

CLM preparation. Membrane fractions were prepared by adapting the detergent-free method of Smart et al. (1995). Briefly, pools of 40-50 P7 ERKO neocortices were homogenized in $20 \mathrm{~mm}$ Tricine, $\mathrm{pH} 7.8$, buffer, containing $1 \mathrm{~mm}$ EDTA, $0.25 \mathrm{M}$ sucrose, and $1 \mathrm{~mm}$ dithiothreitol (TESD buffer), then centrifuged at $1000 \times g$ at $4^{\circ} \mathrm{C}$ for $10 \mathrm{~min}$. The pellet was resuspended in TESD buffer, recentrifuged, and the supernatants were pooled. The combined supernatants were subjected to Percoll gradient fractionation in the same buffer to isolate the plasma membrane fraction. In some binding experiments (indicated below) Percoll-purified plasma membranes were used without further fractionation. For preparation of CLMs, plasma membranes were sonicated and further separated by centrifugation on a linear 20 to 10\% OptiPrep (iodixanol) gradient (Nycomed Pharma A. S, Oslo, Norway). Based on their light-buoyant density, CLMs were separated and purified from non-CLMs, using two OptiPrep density gradients. The purity of the CLM preparation was verified immunologically by demonstrating the presence of CLMenriched proteins: flotillin (1:250), PKC- $\alpha$ and PKC- $\gamma(1: 1000)$ (Transduction Labs, Lexington, KY), and absence of the non-CLM-associated cytoskeletal protein paxillin (1:10,000; Transduction Labs). Electrophoretically separated CLMs on PVDF membranes were probed with antibodies specific for ER- $\alpha$ [C1355, (Upstate Biotechnology); MC20 (Santa Cruz Biotechnology)]; ER- $\beta$ (Zymed); flotillin (Transduction Labs) and other caveolar-resident proteins: e.g., PKC- $\alpha$ and PKC- $\gamma$ (Transduction Labs) and noncaveolar-resident proteins: e.g., paxillin (Transduction Labs)].

Phosphorylation of ERK1/2 in CLM and non-CLM preparations. Phosphorylation of ERK1/2 in ERKO CLM and non-CLM preparations was examined following the method of Liu et al. (1997), except that basal medium Eagle (BME) was used in the place of MEM. Nine parts of CLM or non-CLM preparations were mixed with one part of $10 \times \mathrm{BME}$, pH 7.4, containing BSA $800 \mu \mathrm{g} / \mathrm{ml}, 10 \mathrm{~mm} \mathrm{NaF}, 2$ mM Na3VO4, leupeptin $100 \mu \mathrm{g} / \mathrm{ml}$, soybean trypsin inhibitor $100 \mu \mathrm{g} / \mathrm{ml}, 10 \mathrm{mM} \mathrm{MgCl}_{2}$, and 1 mM ATP. For MAP kinase kinase (MEK)1/2 inhibition of ERK activation, the CLMs were pretreated with the MEK1/2 inhibitor, U0126 (10 $\mu \mathrm{M}$; Cell Signaling, Beverly, MA) for $30 \mathrm{~min}$ before pulsing them with the appropriate estradiol. Aliquots of ERKO CLMs and non-CLMs were exposed for $30 \mathrm{~min}$ at $37^{\circ} \mathrm{C}$ to either $17 \alpha$-estradiol $(0.1 \mathrm{nM}), 17 \beta$-estradiol (10 nM), U0126 (10 $\mu \mathrm{M})$ or a sham control and processed for ERK1/2 phosphorylation, using antibodies to phosphorylated p44/42 MAP Kinase (ERK1/2) (Thr202/Tyr204) (Cell Signaling Technology), as previously described (Singh et al., 1999, 2000).

Isolation of PNS. To increase the yield of ER-X and to test in a cell-free system whether the presence of ER- $\alpha$ is inhibitory for ERK activation, as we had shown previously in neocortical cultures (Singh et al., 2000), we also studied PNS, a cell-free system that contains all the cell organelles except the nucleus. PNS was isolated from P7 wild-type and ERKO neocortices, according to the method of Smart et al. (1995). Three or four P7 wild-type and ERKO neocortices were homogenized, using a Teflon homogenizer in $1 \mathrm{ml}$ of $20 \mathrm{~mm}$ Tricine, $\mathrm{pH} 7.8$, buffer, containing $1 \mathrm{~mm}$ EDTA, $0.25 \mathrm{M}$ sucrose, $10 \mu \mathrm{g} / \mathrm{ml}$ aprotinin, and $1 \mu \mathrm{g} / \mathrm{ml}$ leupeptin. The homogenate was centrifuged at $1000 \times g$ at $4^{\circ} \mathrm{C}$ for $10 \mathrm{~min}$. The supernatant obtained is the PNS. The pellet was resuspended in $500 \mu \mathrm{l}$ of the homogenization buffer, recentrifuged, and the PNS obtained was pooled with the first PNS. ERKO and wild-type PNS were mixed with $10 \times$ phosphorylation buffer, and the MAPK assay was performed as described above. PNS samples were exposed to $17 \alpha$-estradiol $(0.1 \mathrm{nM})$, $17 \beta$-estradiol $(10 \mathrm{nM})$, the ER- $\alpha$-selective ligand propylpyrazole triol (PPT) (100 nM) (Stauffer et al., 2000) (a gift from J. A. Katzenellenbogen, University of Illinois, Champaign/Urbana), the MEK inhibitor U0126 (10 $\mu \mathrm{M})$, BDNF (100 ng/ml), ethanol (0.001\%), DMSO (0.001\%), and a sham control; first, for $10 \mathrm{~min}$ at $4^{\circ} \mathrm{C}$, followed by $10 \mathrm{~min}$ at $37^{\circ} \mathrm{C}$.

Cholesterol depletion. To determine whether disruption of CLMs impairs estrogen activation of the MAPK cascade, neocortical explants were pretreated on P9 with the sterol binding agent Nystatin $(50 \mu \mathrm{g} / \mathrm{ml})$ (Sigma), a compound used extensively to document the association of growth factor receptors with caveolae/CLMs (Huang et al., 1999). This concentration of Nystatin has been shown to result in a significant reduction of cellular cholesterol content without appreciably affecting cell viability (Rothberg et al., 1990). P9 neocortical explants were exposed to Nystatin $(50 \mu \mathrm{g} / \mathrm{ml})$ (Sigma), BDNF (100 $\mathrm{ng} / \mathrm{ml})$, or vehicle control (PBS) for $1 \mathrm{hr}$ before pulsing with $10 \mathrm{~nm} 17 \beta$-estradiol for $30 \mathrm{~min}$, in the continued presence of inhibitor, BDNF, or vehicle. Explants were then processed by Western immunoblot analysis for phosphoERK ex- pression, using antibodies to phosphorylated p44/42 MAP Kinase (ERK1/2) (Thr202/Tyr204) (Cell Signaling Technology), as previously described (Singh et al., 1999, 2000).

In situ hybridization. Explants of the ERKO neocortex were processed for in situ hybridization, after $7 \mathrm{~d}$ in vitro, by a very sensitive, nonisotopic (digoxigenin) method, using a 48 base oligodeoxyribonucleotide (oligonucleotide) to an $\alpha$-specific sequence of the ER- $\alpha$ LBD (BER2), as previously described (Miranda and Toran-Allerand, 1992). Briefly, the probe was 3 '-end-labeled with digoxigenin-labeled deoxyuridine triphosphate (dUTP) by terminal deoxynucleotidyl transferase (TdT) (Invitrogen, Grand Island, NY). After hybridization of the synthetic oligonucleotide to the target cDNA, the hybrids were detected by enzyme-linked immunohistochemistry, using anti-digoxigenin antibodies (Fab fragment), conjugated to alkaline phosphatase (1:500; Boehringer Mannheim, Indianapolis, IN), and an enzyme-catalyzed blue-color reaction (5-bromo-4-chloro-3-indolyl phosphate and nitro-blue tetrazolium salt).

Immunocytochemistry. P7 ERKO and wild-type mice were anesthetized by hypothermia and killed painlessly by transcardial perfusion of saline, followed by $4 \%$ paraformaldehyde and $1 \%$ glutaraldehyde fixation. The neocortex was processed by pre- and post-embedding immunocytochemistry for ER- $\alpha$ and flotillin, respectively. Sections $(50 \mu \mathrm{m})$ were incubated in anti-ER- $\alpha$ antibodies (C1355, 1:1000; or 6F11, 1:50), washed, and incubated in biotinylated horse-anti-rabbit or anti-mouse IgG, 1:250 (Vector Laboratories), incubated with avidin-biotinperoxidase, 1:50 (Vector Laboratories), and followed by diaminobenzidine (DAB) (brown reaction product). Sections were then processed for electron microscopy, dehydrated, and flat embedded in Durcupan (EM Science, Gibbstown, NJ). Alternate ultrathin sections (Reichert-Jung Ultramicrotome) of the neocortex, immunolabeled for ER- $\alpha$, were further labeled for flotillin (1:50). Sections were washed and incubated in gold-conjugated $(15 \mathrm{~nm})$ goat anti-rabbit IgG (1:20) (EM Science), then washed and contrasted with saturated uranyl acetate. Ultrathin sections were examined using a Philips CM-10 electron microscope.

Estrogen binding assay. Duplicate aliquots of $1 \mathrm{mg}$ each of protein lysate from ERKO P7 neocortex or wild-type adult uterus were precleared for $30 \mathrm{~min}$, using anti-rabbit IgG-coated magnetic beads (Dynal AS). Precleared protein lysates were immunoprecipitated with anti-ER- $\alpha$ antibodies [6F11 (Novocastra) or MC20 (Santa Cruz Biotechnology)] at $4^{\circ} \mathrm{C}$ overnight. Immunoprecipitated samples, Percoll-purified plasma membrane fractions, and Optiprep-purified CLM preparations (50 $\mu \mathrm{g}$ each) from P7 wild-type or ERKO neocortex were incubated with ${ }^{3} \mathrm{H}$ estradiol $\left(2,4,6,7,16,17-{ }^{3} \mathrm{H}\right.$-estradiol, $100 \mathrm{Ci} / \mathrm{mmol}$; NEN Life Sciences, Boston, MA) at $4^{\circ} \mathrm{C}$ for $18 \mathrm{hr}$. The incubation was terminated by adsorption of the binding sites onto an equal volume of hydroxylapatite (HAP) slurry in TESD buffer. HAP pellets were washed four times with Tris-buffered saline containing $0.2 \%$ Tween 20 buffer and extracted with $1 \mathrm{ml}$ of absolute ethanol overnight at room temperature. The ethanol supernatants were transferred to liquid scintillation fluid $(5 \mathrm{ml})$ and counted. Control tubes, used in assessing HAP adsorption of free steroid, contained HAP and the same buffer constituents, without addition of the membranes. Nonspecific binding was assayed in the membranes using the same amount of radioactive ligand plus 200-fold molar excess of unlabeled diethylstilbestrol (DES) (Sigma). Specific binding was calculated by subtracting nonspecific from total binding. The apparent affinity of the membrane binding sites was determined by incubation with a range of concentrations of ${ }^{3} \mathrm{H}$-estradiol $(0.25-10 \mathrm{nM})$. The specificity of the binding sites was studied by coincubation of purified membranes with $2 \mathrm{nM}$ ${ }^{3} \mathrm{H}$-estradiol in the presence of unlabeled progesterone, $17 \alpha$-estradiol, or $17 \beta$-estradiol, added at either 25 -fold or 500 -fold molar excess.

Transient cerebral ischemia model. Details of the murine model of focal cerebral ischemia, using an intraluminal suture, have been described previously (Huang et al., 2000). Briefly, mice were anesthetized with 0.3 $\mathrm{ml}$ of intraperitoneal ketamine $(10 \mathrm{mg} / \mathrm{ml})$ and xylazine $(0.5 \mathrm{mg} / \mathrm{ml})$ and positioned supine on a rectal temperature-controlled operating surface (Yellow Springs Instruments, Yellow Springs, OH). Animal core temperature was maintained at $37 \pm 2^{\circ} \mathrm{C}$ during surgery and for $90 \mathrm{~min}$ after surgery. A midline neck incision exposed the right carotid sheath under the operating microscope (Leica). The common carotid artery was isolated and the occipital, pterygopalatine, and external carotid arteries were each isolated, cauterized, and divided. Middle cerebral artery occlusion was accomplished by advancing a $13 \mathrm{~mm}$ heat-blunted 6-0 nylon suture via an arteriotomy made in the external carotid stump. After placement of the occluding suture, the external carotid artery was cauterized to prevent bleeding through the arteriotomy, and arterial flow was established. After $45 \mathrm{~min}$ the occluding suture was removed, and 
electrocautery was used to close the arteriotomy. The wound was closed with surgical staples. After $24 \mathrm{hr}$, the mice were anesthetized, decapitated, and brains were removed intact and placed in a mouse brain matrix (Activational Systems Inc, Warren, MI) for $1 \mathrm{~mm}$ sectioning. Sections were immersed in $2 \%$ triphenyltetrazolium chloride (Sigma) in $0.9 \%$ saline and incubated for $12 \mathrm{~min}$ at $37^{\circ} \mathrm{C}$. Infarcted brain was identified as an area of unstained tissue. Slices containing tissue from the region surrounding the infarct (penumbra) and from the comparable region of the noninfarcted hemisphere were processed for immunoprecipitation and Western analysis, using $6 \mathrm{~F} 11$ and $\mathrm{MC} 20$ antibodies to ER- $\alpha$, respectively. A total of 8 wild-type mice were studied.

\section{RESULTS}

\section{P7 neocortex contains an $\sim 62-63 \mathrm{kDa}$ protein that is neither ER- $\alpha$ nor ER- $\beta$ and is enriched in CLMs of the plasma membrane}

Using antibodies directed against ER- $\alpha$ and ER- $\beta$, we found, by immunoprecipitation and Western immunoblot analysis of wildtype and ERKO P7 neocortical cell lysates, PNS, and CLM preparations, an hitherto unidentified protein, immunoreactive for the LBD of ER- $\alpha$ but not ER- $\beta$. We propose that this protein represents ER-X. Although immunoreactive for ER- $\alpha$, this protein has an apparent MW of $\sim 62-63 \mathrm{kDa}$ that is clearly different from that of ovarian ER- $\alpha(67 \mathrm{kDa})$ and ER- $\beta$ (60 kDa) (Fitzpatrick et al., 1999) (Fig. 1a). Cell lysates and detergent-free, highly purified, CLM preparations (Smart et al., 1995) of both P7 neocortical wild-type and ERKO plasma membranes expressed this $\sim 62-63 \mathrm{kDa}$ protein (Fig. 1b). Although P7 wild-type neocortex expressed both the $67 \mathrm{kDa}$ ER- $\alpha$ band and the $\sim 62-63$ $\mathrm{kDa}$ ER-X band, P7 ERKO neocortex contained only the $\sim 62-63$ $\mathrm{kDa}$ band. P7 wild-type and ERKO neocortical CLM preparations were greatly enriched with the $\sim 62-63 \mathrm{kDa}$ protein (Fig. $1 b)$. A striking reversal of the $67 \mathrm{kDa} / \sim 62-63 \mathrm{kDa}$ ratio was seen in wild-type P7 neocortical CLM preparations, which, although highly enriched in the $\sim 62-63 \mathrm{kDa}$ form, were greatly diminished in the $67 \mathrm{kDa}$ ER- $\alpha$ band. The specificity and significance of the association of the $\sim 62-63 \mathrm{kDa}$ protein with CLMs was emphasized by the failure to detect immunoreactivity for other steroid receptors, such as ER- $\beta$ in CLM, non-CLM, and plasma membrane preparations (Fig. 1c), although its presence was clearly demonstrable in P7 neocortical cell lysates and in the nuclear fraction and PNS (Fig. 1c).

The purity of the CLM preparations was verified by demonstrating the presence of the CLM integral protein flotillin (Bickel et al., 1997) (Fig. 2a) and such CLM-enriched resident proteins as PKC- $\alpha$ (Fig. $2 b$ ) and PKC- $\gamma$ (data not shown) (Smart et al., 1995), and by the absence of the cytosolic protein paxillin (Fig. 2c), a cytoskeletal component associated with non-CLM regions of plasma membranes (Smart et al., 1995).

\section{ER-X has an entirely different steroid specificity than either ER- $\boldsymbol{\alpha}$ or ER- $\boldsymbol{\beta}$}

The steroid specificity for estrogen-induced activation of ERK1/2 phosphorylation is radically different from that of either ER- $\alpha$ or ER- $\beta$ : ERK1/2 is not activated by either ER$\alpha$-selective ligands such as $16 \alpha$-iodo- $17 \beta$-estradiol (Singh et al., 2000) and PPT (Stauffer et al., 2000) (100 nM) (see Fig. 4b,c) or by ER- $\beta$-selective ligands such as genistein and coumestrol (Singh et al., 2000) but is activated equally well by picomolar concentrations of $17 \alpha$ - and $17 \beta$-estradiol (Fig. 3a,b). In wildtype cultures $17 \alpha$-estradiol, a natural stereoisomer of $17 \beta$ estradiol that is generally considered to be transcriptionally inactive, elicited a stronger, sustained activation of ERK1/2 at



Figure 1. ER-X is neither ER- $\alpha$ nor ER- $\beta$. $a$, Western immunoblots of P7 wild-type and ERKO neocortex and adult wild-type mouse ovary, using antibodies to the LBDs of ER- $\alpha$ (Santa Cruz Biotechnology; MC20 ; ovary and neocortex) and ER- $\beta$ (Zymed; ovary). The apparent MW of ER-X $(\sim 62-63 \mathrm{kDa})$ is clearly different from the MW of the mouse ER- $\alpha$ $(67 \mathrm{kDa})$ and ER- $\beta(60 \mathrm{kDa})$ ovarian controls. $b$, Whereas P7 wild-type neocortex contained both the $67 \mathrm{kDa}$ ER- $\alpha$ and the $\sim 62-63 \mathrm{kDa}$ ER-X bands, P7 ERKO tissues expressed only the $\sim 62-63 \mathrm{kDa}$ ER-X band. P7 wild-type and ERKO neocortical CLM preparations were greatly enriched with the $\sim 62-63 \mathrm{kDa}$ protein. A striking reversal of the ER- $\alpha /$ ER-X ratio was seen in wild-type CLM preparations, in which the $\sim 62-63 \mathrm{kDa}$ form was highly enriched, whereas authentic $67 \mathrm{kDa}$ ER- $\alpha$ was considerably diminished. $c$, Absence of ER- $\beta$ from the plasma membrane, CLM, and non-CLM regions. Note the total absence of ER- $\beta$ from the wild-type plasma membrane and the CLM and non-CLM fractions. Note also the nuclear concentration of the 60 and $64 \mathrm{kDa}$ isoforms of ER- $\beta$. PM, Plasma membrane; non-CLM, non-caveolar-like membrane; $C L M$, caveolar-like membrane.

the $1-10 \mathrm{pm}\left(10^{-12} \mathrm{M}\right)$ range (Fig. $\left.3 b\right)$ than did $17 \beta$-estradiol (0.1-10 nM) (Fig. 3a). What makes this response so astonishing is that $17 \alpha$-estradiol, which, like $17 \beta$-estradiol, is derived from aromatization of androgens, but whose site of synthesis is unclear, has a 100-fold lower affinity for ER- $\alpha$ than $17 \beta$ estradiol (Hajek et al., 1997). Significantly, higher levels of $17 \beta$-estradiol were required for ERK activation in wild-type neocortical cultures (Fig. $3 a$ ), perhaps reflecting the need to overcome the inhibitory effect of ER- $\alpha$ on ERK1/2 phosphorylation (Singh et al., 2000) (Fig. 4), which, unlike $17 \alpha$-estradiol, $17 \beta$-estradiol activates as well. That the inhibitory presence of ER- $\alpha$ influences dose responsiveness is suggested by observation that in the ER- $\alpha$-deficient ERKO neocortical explants, $17 \beta$-estradiol, like $17 \alpha$-estradiol, is also able to elicit activation of ERK in the 1-10 pM range (data not shown). 


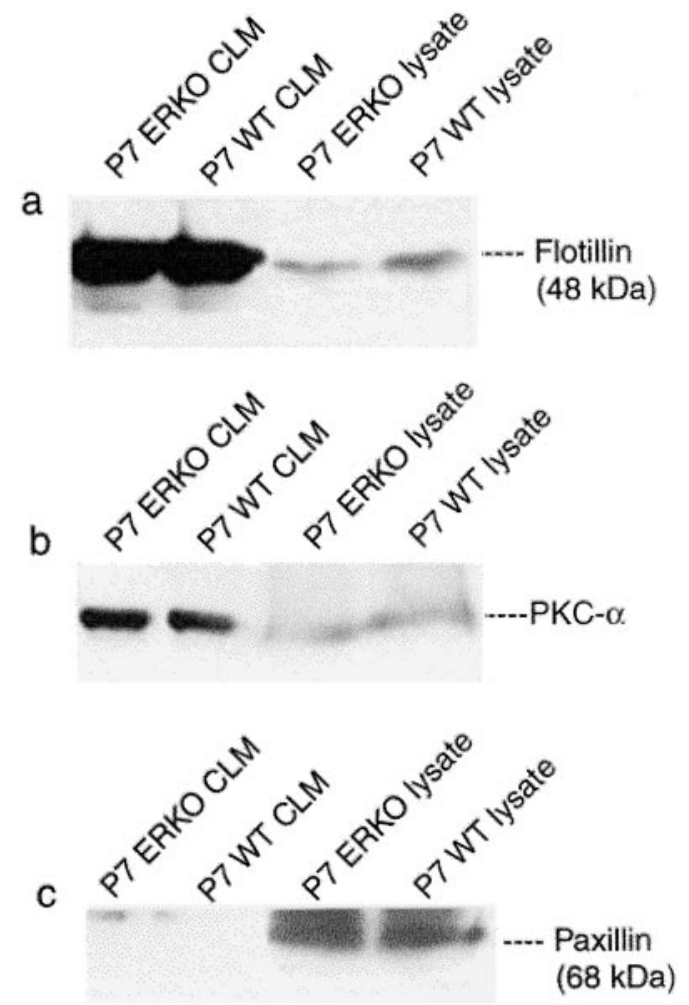

Figure 2. Characterization and purity of the CLM preparations. $a$, Western immunoblots of CLMs show enrichment in flotillin, the neuronspecific, integral CLM protein. The purity of CLM preparations was verified by the presence of caveolar-enriched resident proteins such as PKC $-\alpha(b)$, and by the absence of the cytosolic protein paxillin, a cytoskeletal component associated with non-CLM regions $(c)$.

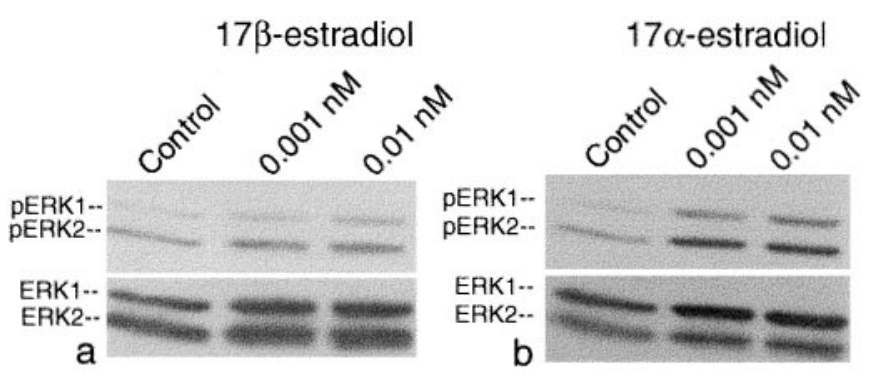

Figure 3. ER-X is exquisitely sensitive to picomolar concentrations of $17 \alpha$ - and $17 \beta$-estradiol. Western immunoblot of ERK1/2 phosphorylation elicited in wild-type neocortical explants by $17 \beta$-estradiol $(a)$ and $17 \alpha$ estradiol $(b)$. Bottom blots, Reprobing with antibodies to total nonphosphorylated ERK1/2 to verify equal loading of ERK1/2 protein across lanes. $p E R K$, phosphoERK. Densitometry confirmed equal loading. Note that significantly higher levels of $17 \beta$-estradiol were required for ERK activation, perhaps reflecting the need in wild-type cultures to overcome the inhibitory effect of ER- $\alpha$ on ERK phosphorylation, which, unlike $17 \alpha$-estradiol, $17 \beta$-estradiol activates as well.

\section{Estrogen elicits ERK1/2 activation in CLMs}

To provide direct evidence that the CLM-associated $\sim 62-63$ $\mathrm{kDa}$ ER-X protein is connected with estrogen-induced ERK1/2 activation, we showed that exposure of highly purified, P7 ERKO neocortical CLMs to $17 \beta$-estradiol (10 nM) and $17 \alpha$-estradiol (0.1 $\mathrm{nM}$ ) for 30 min elicited phosphorylation of ERK1/2 (Fig. 4a). In both instances ERK activation was inhibited by the MEK inhibitor U0126 (Fig. 4a). In contrast, non-CLM regions of the plasma membrane, exposed similarly, did not respond (Fig. 4a).

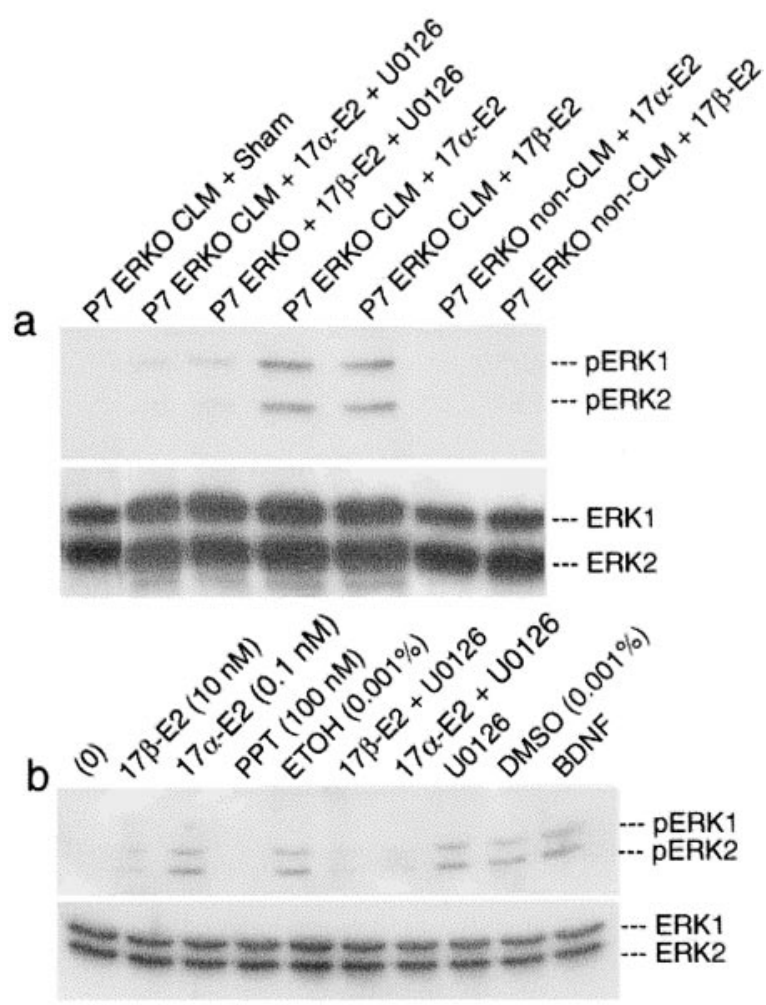

C



Figure 4. Estrogen-induced activation of ERK1/2 in CLMs and PNS. Western immunoblots: $a$, exposure of highly purified, P7 ERKO neocortical CLMs to $17 \alpha$-estradiol ( $0.1 \mathrm{nM}$ ) and $17 \beta$-estradiol (10 nM) for $30 \mathrm{~min}$ elicited MEK-dependent (U0126) phosphorylation of ERK1 and ERK2. Non-CLM regions were unresponsive. Densitometry confirmed equal loading of protein. $b$, Exposure of P7 wild-type neocortical PNS to $17 \alpha$-estradiol $(0.1 \mathrm{nM})$ and $17 \beta$-estradiol $(10 \mathrm{nM})$ for $10 \mathrm{~min}, 37^{\circ} \mathrm{C}$ elicited MEK-dependent (U0126) phosphorylation of ERK1 and ERK2. Note that, not only did the ER- $\alpha$-selective ligand PPT reduce ERK phosphorylation levels below baseline $(0)$ very significantly, but that the level of ERK1/2 phosphorylation, elicited by $17 \beta$-estradiol, was also significantly lower than after exposure to $17 \alpha$-estradiol. This difference may be attributed to the fact that P7 wild-type neocortex is also enriched in ER- $\alpha$ which, because it is activated by $17 \beta$ - (but not $17-\alpha$ ) estradiol and exerts its inhibitory effect on ERK1/2, as was also seen after exposure to PPT. Bottom blots, Reprobing with antibodies to nonphosphorylated ERK1/2 to verify equal loading of ERK protein across lanes. Densitometry confirmed equal loading. $c$, Densitometric analysis of ERK activation in wild-type PNS shown in $b$. These findings confirm that ER- $\alpha$ is a strong inhibitor of ERK activation, a measure of which is shown by the ability of PPT to effectively prevent ERK activation even in the face of the strong activation of ERK elicited by the PPT vehicle ethanol. 


\section{ER- $\alpha$ is an inhibitory regulator of ERK1/2 activation in PNS}

We then investigated in wild-type PNS, a cell-free system, whether ER- $\alpha$ is an inhibitory regulator of estrogen-induced ERK1/2 activation, as we had shown previously in neocortical explants (Singh et al., 2000). Using the ER- $\alpha$-selective ligand PPT (Stauffer et al., 2000) (100 nM) in wild-type neocortical PNS, we found that MEK-inducible ERK1/2 phosphorylation was dramatically reduced below baseline (Fig. $4 b$ ). Of particular note, furthermore, were the findings that the levels of $17 \beta$-estradiolinduced ERK1/2 phosphorylation were significantly less than after exposure to $17 \alpha$-estradiol, although both were inhibited by the MEK inhibitor U0126. This difference in responsiveness may be attributed to the fact that, at P7, wild-type neocortex is also enriched with maximal levels of ER- $\alpha$ (Gerlach et al., 1983) which, when activated by $17 \beta$ - (but not 17- $\alpha$ ) estradiol, is able to exert its inhibitory effect on ERK1/2, as is also seen after exposure to PPT. These findings confirm that ER- $\alpha$ is a strong inhibitor of ERK1/2 activation, a measure of which is given by the ability of PPT to effectively prevent activation of ERK1/2 even in the face of strong ERK1/2 activation, elicited by the PPT vehicle ethanol (Fig. 4b,c). These findings provide not only additional proof that ER- $\alpha$ does not mediate activation of the MAPK cascade but also compelling evidence confirming the role of ER- $\alpha$ as an inhibitory modulator of ERK1/2 activation.

\section{Cholesterol disruption in CLMs decreases estrogen activation of ERK}

CLMs, like caveolae, are highly enriched in cholesterol, glycosphingolipids, sphingomyelin, and lipid-anchored membrane proteins, which serve as multivalent scaffolding onto which many signaling kinases assemble to generate preassembled signaling complexes. Eighty to ninety percent of plasma membrane cholesterol is concentrated within caveolae/CLMs, where it plays a critical role in maintaining receptor protein association within the CLM domain (Rothberg et al., 1990). The sterol-binding agent Nystatin has been used extensively to document the association of growth factor receptors with caveolae/CLMs (Huang et al., 1999). To determine whether selective disruption of cholesterol in CLMs impairs the ability of estrogen to elicit ERK1/2 phosphorylation, we exposed P9 neocortical explants to Nystatin $(50 \mu \mathrm{g} /$ $\mathrm{ml})$ for $1 \mathrm{hr}$ before pulsing with $17 \beta$-estradiol (10 nM), BDNF (100 ng/ml), or the vehicle control (PBS) for $30 \mathrm{~min}$ (Fig. 5) and then processing for ERK1/2 phosphorylation by Western blot analysis. We found that disruption of membrane cholesterol decreased the ability of both estradiol and BDNF to elicit ERK1/2 phosphorylation, providing additional evidence of the contributions of CLMs to estradiol-induced ERK1/2 activation.

\section{ER-X has homology with ER- $\alpha$ LBD and is expressed in the plasma membrane}

Using an oligonucleotide probe directed against an $\alpha$-specific region of the ER- $\alpha$ LBD (BER2) (Miranda and Toran-Allerand, 1992), we found widespread distribution of the blue ER- $\alpha$-like hybridization signal in neurons of cultured slices of the ER- $\alpha$ deficient P2 ERKO neocortex, $17 \mathrm{~d}$ in vitro (Fig. 6). This pattern of hybridization in ERKO neocortex suggests that, in view of the absence of ER- $\alpha$, the oligonucleotide sequence used may share some homology with ER-X mRNA.

Direct evidence that ER-X may be a neuronal plasma membrane-associated ER protein with some homology to ER- $\alpha$ was also obtained in the ERKO neocortex by means of light and

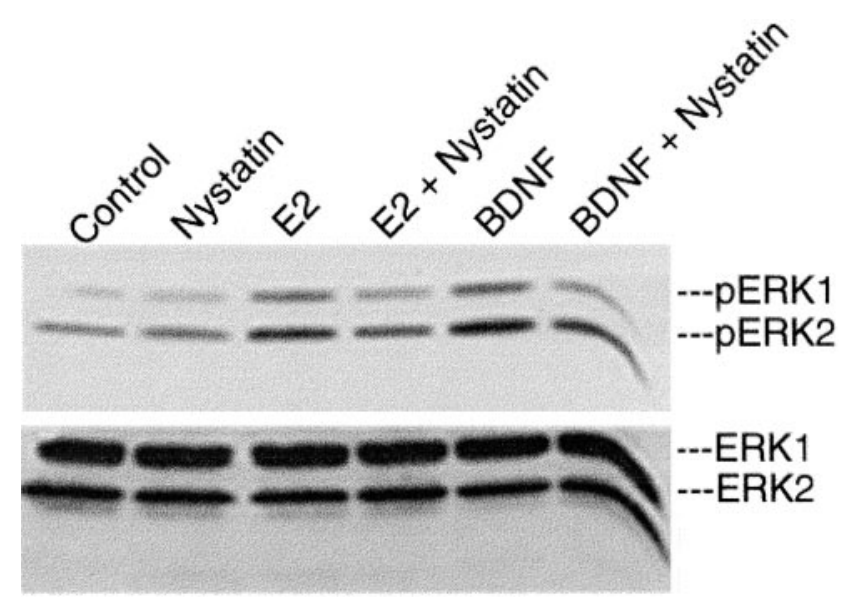

Figure 5. Disruption of cholesterol in CLMs impairs ERK activation. Selective disruption of membrane cholesterol by Nystatin in 9-d-old wild-type neocortical explants decreased the ability of estradiol and the BDNF control to elicit ERK phosphorylation. Bottom blots, Reprobing with antibodies to nonphosphorylated ERK1/2 to verify equal loading of ERK protein across lanes. Densitometry confirmed equal loading.

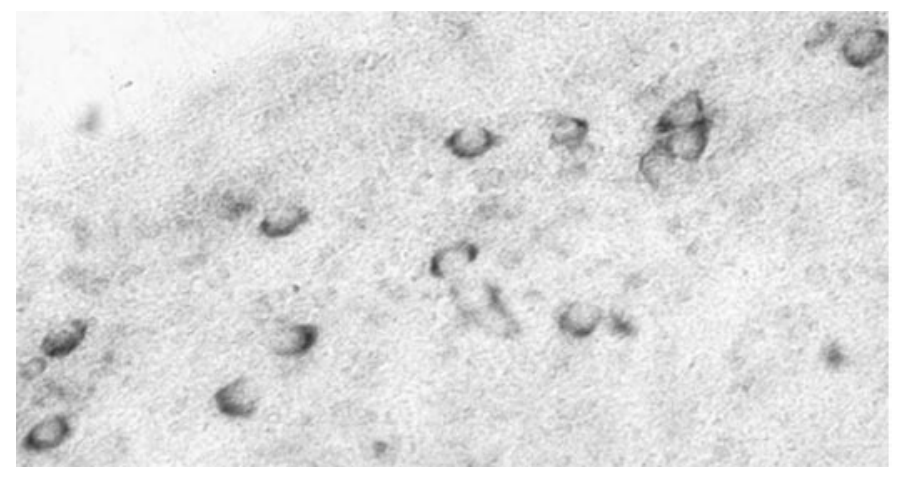

Figure 6. ER-X has homology with the LBD of ER- $\alpha$. Whole-mount of a P2 ERKO neocortical explant, $17 \mathrm{~d}$ in vitro. The culture was stained for ER- $\alpha$ mRNA by in situ hybridization with a 48 base oligonucleotide probe to an $\alpha$-specific region of the ER- $\alpha$ LBD (BER2; Miranda and ToranAllerand, 1992) and shows the ER- $\alpha$-like mRNA hybridization signal in neocortical neurons. Residual, untranslated ER- $\alpha$ mRNA? A splice variant of ER- $\alpha$ mRNA? Or the mRNA for a novel ER, ER-X?

electron microscopic immunohistochemistry (Fig. 7a-e). Using polyclonal antibodies, generated against the final $14 \mathrm{C}$-terminal amino acids of the rat ER and highly specific for ER- $\alpha$ (C1355, Upstate Biotechnology) (Schreihofer et al., 1999), large numbers of immature ERKO neocortical neurons with unstained nuclei were seen (Fig. 7a,b). Immunoreactivity was clearly localized to the cell membrane and cytoplasm and not in the nucleus. In Figure $7 b$, a blood vessel $(V)$ is in close proximity to a labeled dendrite, an association which suggests a mechanism by which estrogen could get even more efficiently onto ER-X. On the other hand, using monoclonal antibodies generated against full-length mouse ER- $\alpha$ (6F11; Novocastra) (Fig. 7D,E) and said to recognize the $5^{\prime} \mathrm{N}$ terminus region, the opposite result was obtained: nuclear labeling was observed but no cytoplasmic or membrane labeling was seen. Because we have found that $6 \mathrm{~F} 11$ cross-reacts significantly with ER- $\beta$ by Western blotting (data not shown), the nuclear labeling observed here most likely reflects intranuclear ER- $\beta$, which is normally expressed in both wild-type and ERKO neocortex. Association of the $\sim 62-63 \mathrm{kDa}$ protein with CLMs 


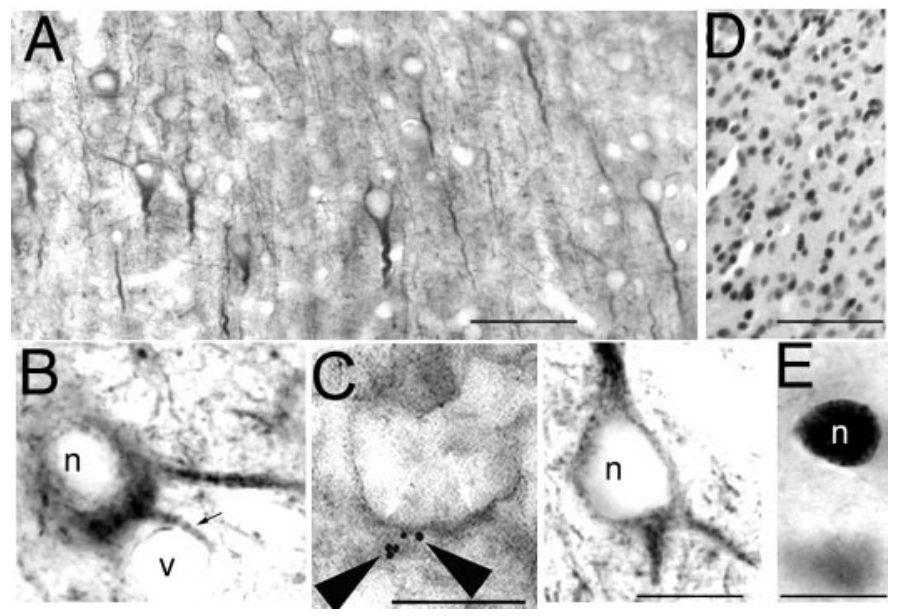

Figure 7. Direct evidence in ERKO that ER-X is a neuronal plasma membrane-associated receptor with some homology to the ER- $\alpha$ LBD. $A$, Using antibodies highly specific for an $\alpha$-specific region of the LBD of ER- $\alpha$ (C1355), large numbers of immature immunoreactive neocortical ERKO neurons with unstained nuclei are seen. $B$, The immunoreactivity is clearly localized to the cell membrane and cytoplasm and not in the nucleus. $D, E$, Antibodies, raised against the full-length ER- $\alpha$ molecule, said to recognize epitopes in the $5^{\prime}, \mathrm{N}$-terminal region (6F11), but which we have found also to cross-react significantly with ER- $\beta$, show widespread nuclear labeling with no cytoplasmic or membrane labeling seen. The nuclear labeling observed most likely reflects intranuclear ER- $\beta$, which is normally expressed in both wild-type and ERKO neocortical neurons. $C, C L M$ association of ER-X in ERKO neocortical neurons was further documented at the ultrastructural level by demonstrating immunoreactive flotillin (gold particles), colocalized with immunoreactivity for the ER- $\alpha$ LBD (horseradish peroxidase) on a mushroom-like neocortical dendritic spine. Scale bars, $10 \mu \mathrm{m}$.

was further documented at the ultrastructural level on ultrathin cryostat sections of P7 ERKO neocortex by demonstrating immunoreactive flotillin, labeled by gold particles, colocalized with horseradish peroxidase-labeled immunoreactivity for ER- $\alpha$ on a neocortical dendritic spine (Fig. 7C).

\section{ERKO neocortical plasma membranes contain an estrogen-binding protein (ER-X)}

We determined that neocortical plasma membranes contain a unique estrogen-binding protein by scintillation counting of ${ }^{3} \mathrm{H}$ estradiol binding to the $\sim 62-63 \mathrm{kDa}$ ER-X protein in highly purified P7 ERKO CLM preparations. In these preparations, the only detectable ER-immunoreactive material present was the $\sim 62-63 \mathrm{kDa}$ protein (Fig. 1). Binding of $10 \mathrm{nM}{ }^{3} \mathrm{H}$-estradiol to $\mathrm{P} 7$ ERKO CLMs appeared to be specific and saturable, in that it was suppressed in the presence of unlabeled diethylstilbestrol (DES). Neocortical CLM preparations from P7 ERKO mice, shown to be highly enriched in ER-X, were similarly highly enriched in DESsensitive estrogen binding (282.12 fmol/mg CLM protein), as compared with P7 ERKO neocortical lysates $(9.94 \mathrm{fmol} / \mathrm{mg}$ lysate protein) and wild-type adult uterine lysates $(38.85 \mathrm{fmol} / \mathrm{mg}$ lysate protein). Further characterization of the membrane binding sites was achieved using Percoll-fractionated plasma membranes, containing both CLM and non-CLM components, to increase the yield of total membrane sufficiently to allow construction of binding isotherms and performance of specificity studies. In Percoll-purified membranes from P7 ERKO neocortices, as in CLMs, the only detectable ER-immunoreactive protein present was the $\sim 62-63 \mathrm{kDa}$ band (data not shown). Membranes from both P7 ERKO and P7 wild type neocortex contained a high-
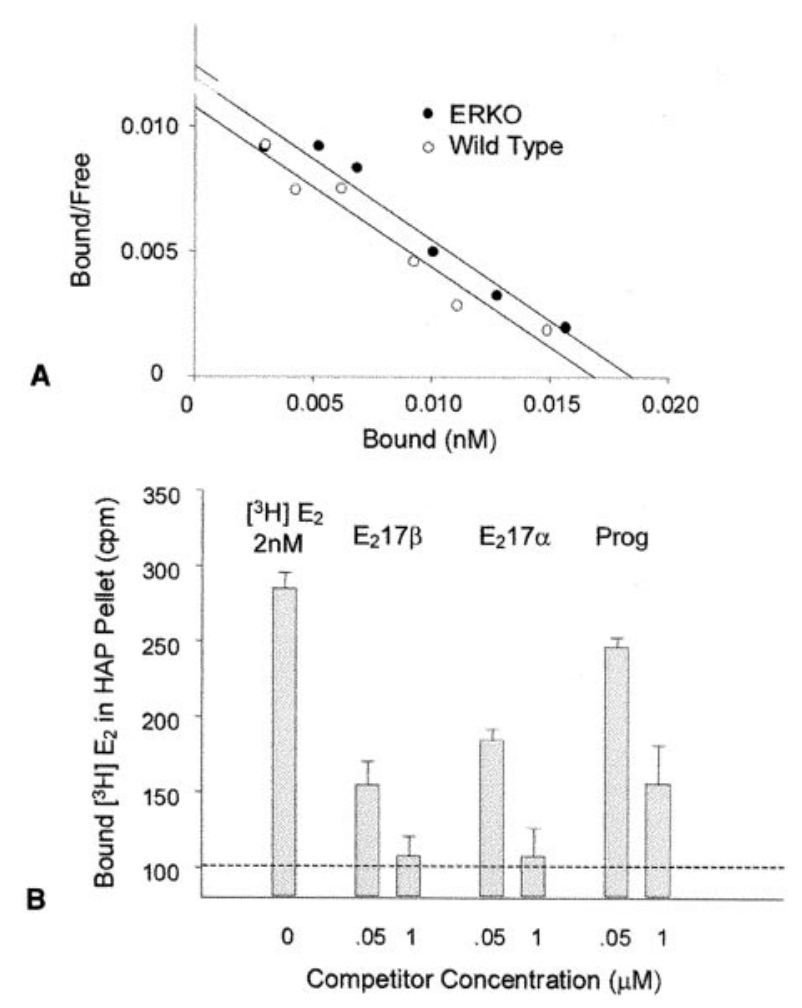

Figure 8. Binding of ${ }^{3} \mathrm{H}$-estradiol to Percoll-purified plasma membranes from P7 ERKO and wild-type mouse neocortex. $A$, Identical amounts of membrane protein $(50 \mu \mathrm{g} /$ tube $)$ were incubated with varying concentrations of ${ }^{3} \mathrm{H}$-estradiol $(0.3-8 \mathrm{~nm})$ for $18 \mathrm{hr}$ at $4 \mathrm{C}$. The reaction was terminated by addition of hydroxylapatite $(H A P)$. The membranes and HAP were sedimented by centrifugation in a microfuge, and the pellet was washed four times to remove free steroid. Radioactivity in the pellets was extracted with ethanol and counted. Nonsaturable binding, assessed in the presence of $1 \mu \mathrm{M}$ unlabeled DES, was subtracted from the total counts, and the saturable binding was plotted as the ratio of boundunbound ligand versus the concentration of bound ${ }^{3} \mathrm{H}$-estradiol. Similar concentrations of high-affinity binding (equilibrium dissociation constant, $\left.K_{\mathrm{d}}, \sim 1.6 \mathrm{nM}\right)$ were observed in wild-type and ERKO membranes. $B$, Specificity of the binding site in Percoll-purified membranes from P7 ERKO mouse neocortex. Aliquots of plasma membrane were incubated with $2 \mathrm{nM}{ }^{3} \mathrm{H}$-estradiol for $18 \mathrm{hr}$ at $4^{\circ} \mathrm{C}$ in the presence and absence of different concentrations (50 nM and $1 \mu \mathrm{M}$ ) of $17 \alpha$-estradiol, $17 \beta$-estradiol, or progesterone. Bound ${ }^{3} \mathrm{H}$-estradiol was separated by sedimentation with HAP and counted at an efficiency of $50 \%$. Data represent the number of bound counts (after subtraction of HAP-only blank control tubes, containing no membrane protein) expressed as the means \pm SD of triplicate determinations. The horizontal dashed line indicates the level of nonspecific binding observed in the presence of $1 \mu \mathrm{M}$ DES.

affinity, saturable ${ }^{3} \mathrm{H}$-estradiol binding site $\left(K_{\mathrm{d}}, \sim 1.6 \mathrm{~nm}\right)$ (Fig. $8 A$ ). Addition of $50 \mathrm{~nm}$ unlabelled $17 \beta$-estradiol or $17 \alpha$-estradiol markedly inhibited binding of ${ }^{3} \mathrm{H}$-estradiol. In the presence of a $1 \mu \mathrm{M}$ concentration of either estrogen, binding of the tritiated ligand was reduced to the nonspecific levels observed in the presence of excess DES (Fig. $8 B$ ). Unlabelled progesterone, by contrast, was less effective than either estrogen, progesterone only partially suppressing binding of ${ }^{3} \mathrm{H}$-estradiol when added in 500 fold molar excess (Fig. 8B).

\section{ER-X is developmentally regulated in the brain and uterus}

Expression of the $\sim 62-63 \mathrm{kDa}$ ER-X protein is developmentally regulated and is maximally expressed $\sim \mathrm{P} 7-\mathrm{P} 10$ in both the neocortex and uterus (Fig. 9a,b). During the first postnatal month, 


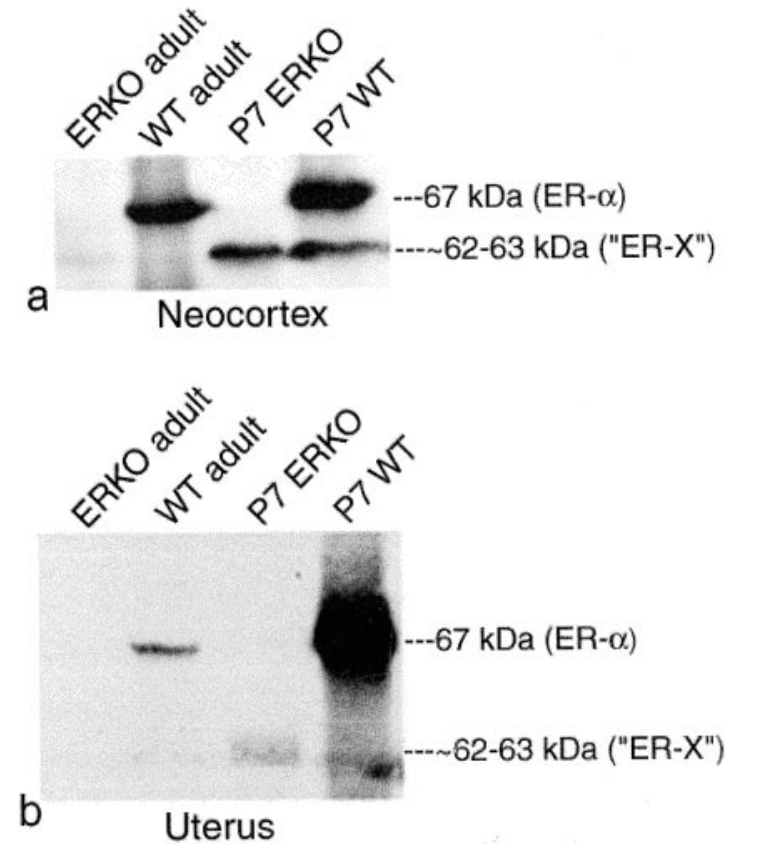

Figure 9. ER-X is developmentally regulated. ER-X expression is developmentally regulated and is maximally expressed at $\sim \mathrm{P} 7-\mathrm{P} 10$ in the neocortex $(a)$ and the uterus $(b)$. During the first postnatal month, wild-type and ERKO neocortical ER-X levels decline dramatically and become barely visible in the adult.

wild-type and ERKO neocortical and uterine levels of the $\sim 62-63 \mathrm{kDa}$ protein declined until P21 and became dramatically reduced in the adult, which expressed little of this protein.

\section{ER-X is upregulated in a rodent model of brain injury}

To test whether re-expression of the developmentally regulated ER-X might return after brain injury in the adult, as has been reported for the developmentally regulated ER- $\alpha$ (Dubal et al., 2001), we analyzed a mouse ischemic stroke model, elicited by transient intraluminal middle cerebral artery occlusion (Huang et al., 2000). Tissue from the region surrounding the infarct (the penumbra) was compared with the comparable region of the noninfarcted neocortex of the opposite side, $24 \mathrm{hr}$ after occlusion. Using immunoprecipitation, followed by Western blotting, we found upregulation of the $\sim 62-63 \mathrm{kDa}$ protein in the penumbra (Fig. 10) to levels comparable with those present during development, as compared with the noninfarcted side that remained unchanged. There was also upregulation of ER- $\alpha$ (Fig. 10), as has been shown previously (Dubal et al., 2001).

\section{DISCUSSION}

These data point strongly to the existence of a novel, plasma membrane-associated, putative estrogen receptor (ER-X). Although membrane ERs have been identified immunologically as ER- $\alpha$ in several cell and tissue systems (Blaustein, 1992; Watson et al., 1999; Razandi et al., 1999; Milner et al., 2001), our findings suggest that ER-X is a unique, functionally distinct, and hitherto unidentified receptor, based on its MW, ligand specificity, cellular localization, and apparent response characteristics. Although ER-X reacts with antibodies to the ER- $\alpha$ LBD, ER-X is not membrane-associated ER- $\alpha$. Its apparent MW of $\sim 62-63 \mathrm{kDa}$ is clearly different from that of both ER- $\alpha(67 \mathrm{kDa})$ and ER- $\beta$ (60 $\mathrm{kDa}$ ) (Fig. 1a). Although a functional isoform of ER- $\beta$ with an additional 18 amino acids inserted in the LBD has been identified

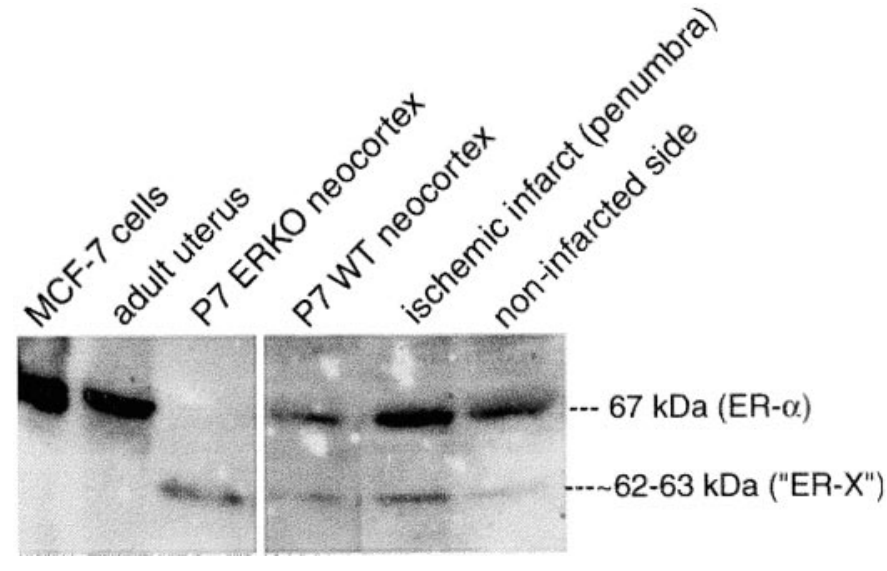

Figure 10. ER-X is upregulated after ischemic brain injury in the adult. Comparison of ER- $\alpha$ and ER-X expression in the infarcted and noninfarcted adult neocortex. After a large ischemic infarct in the neocortex produced by middle cerebral artery occlusion, there was not only upregulation of ER- $\alpha$ expression in the penumbra of the ligated, ischemic side but also upregulation of ER-X therein as well, suggesting re-expression of a developmental mechanism normally latent in the adult. Note the lack of significant ER-X expression on the noninfarcted side. MCF-7 mammary tumor cells and adult uterus $=\mathrm{ER}-\alpha$ controls; P7 neocortex $=\mathrm{ER}-\mathrm{X}$ control.

in rat and mouse tissues (ER- $\beta 2$ ) (Petersen et al., 1998), ER-X cannot represent ER- $\beta 2$, because (1) antibodies directed against the ER- $\alpha$ LBD cross-react with ER-X and do not recognize intranuclear ER- $\beta$. (2) The anti-ER- $\beta$ antibody we used (Zymed) does not react with ER- $\alpha$ but does cross-react on Western blots with the molecular isoforms of rat ER- $\beta$ observed in tissue lysates (N. J. MacLusky and I. S. Nethrapalli, unpublished observations): no immunoreactivity was detected with this antibody in blots from CLMs enriched in ER-X. (3) ERK1/2 is not activated by ER- $\alpha$ or ER- $\beta$-selective agonists (Singh et al., 2000) (Fig. 4b). (4) Unlike ER- $\alpha$ or ER- $\beta, \mathrm{ER}-\mathrm{X}$ is not stereospecific, responding equally well to picomolar concentrations of $17 \alpha$ - and $17 \beta$ estradiol (Fig. $3 a, b$ ), whereas ER- $\alpha$ and ER- $\beta$ exhibit a markedly higher affinity for $17 \beta$ - than for $17 \alpha$-estradiol (Kuiper et al., 1997).

ER-X is part of a multimolecular CLM complex, comprising immunoreactivity for ER- $\alpha$ (but not ER- $\beta$ ) in association with hsp90, members of the MAPK cascade (Toran-Allerand et al., 1999; Singh et al., 1999; Toran-Allerand, 2000) and flotillin, the multivalent, $48 \mathrm{kDa}$ scaffolding protein and neuronal homolog of the caveolar protein caveolin (Bickel et al., 1997). Two recent studies (Levin, 2002; Razandi et al., 2002), published after this paper was submitted, reported association of ER- $\alpha$ immunoreactivity with caveolae in vascular and breast cancer (MCF-7) cells. Although caveolin-associated ER was identified by the authors as ER- $\alpha$ (Razandi et al., 2002), the MW of the immunoreactive band was stated to be $62 \mathrm{kDa}$, not $67 \mathrm{kDa}$, as would be expected for authentic full-length ER- $\alpha$. Rather than demonstrating caveolar association of ER- $\alpha$, as Razandi et al. (2002) concluded, these data are consistent with the observations presented here. In vascular and MCF-7 cells, like neuronal CLMs, caveolarassociated ER- $\alpha$ immunoreactivity represents primarily a protein with an apparent MW $\sim 5 \mathrm{kDa}$ less than that of authentic ER- $\alpha$. In brain, both P7 wild-type and ERKO neocortical CLM preparations were greatly enriched with the immunoreactive $\sim 62-63$ kDa ER-X protein (Fig. 1b) and depleted of ER- $\alpha$ and ER- $\beta$ (Fig. 
$1 b, c)$, supporting the selectivity and specificity of the ER-X association with CLMs.

Surprisingly, in both wild-type and ERKO neocortical explants and CLMs, $17 \alpha$-estradiol, the natural stereoisomer of $17 \beta$ estradiol with 100-fold lower affinity for ER- $\alpha$, (Hajek et al., 1997) also elicited sustained MEK-dependent activation of ERK1/2 in the picomolar range (Figs. $3 b, 4 a, b)$. We showed earlier that ER- $\alpha$ - and ER- $\beta$-selective ligands failed to elicit ERK1/2 activation in wild-type neocortical explants (Singh et al., 2000) and suggested that ER- $\alpha$ may be an inhibitory regulator of ERK activation. This has been confirmed in the PNS cell-free system (Fig. 4b,c). The absence of an inhibitory response in ERKO PNS (data not shown) is consistent with the absence of authentic $67 \mathrm{kDa}$ ER- $\alpha$ from ERKO brains.

Nystatin disrupts cholesterol in cell membranes (Iwabuchi et al., 2000) by forming globular deposits that alter the planar organization of the membrane (McGookey et al., 1983), thereby selectively inhibiting caveolar trafficking without altering other cell functions such clathrin-mediated endocytosis (Ros-Baro et al., 2001) or intracellular receptor trafficking back to the cell surface (Subtil et al., 1999). Nystatin $(50 \mu \mathrm{g} / \mathrm{ml})$ has been shown to significantly reduce cellular cholesterol content without appreciably affecting cell viability. This concentration of Nystatin impaired estradiol induced ERK1/2 activation (Fig. 5).

The existence of plasma membrane-associated ERs (Pietras and Szego, 1977) has been controversial because of previous failures to isolate and characterize such a membrane-associated receptor. Hypothetical mechanisms have included plasma membrane versions of classical intranuclear ER- $\alpha$ and ER- $\beta$ (Blaustein, 1992; Watson et al., 1999; Razandi et al., 1999; Milner et al., 2001), novel members of the ER family (Das et al., 1997; Gu et al., 1999; Nadal et al., 2000), G-protein-coupled receptors (Kelly and Wagner, 1999; Filardo et al., 2000; Wyckoff et al., 2001), or even growth factor-like receptor tyrosine kinases (Anuradha et al., 1994).

That ER-X may have sequence homology with the ER- $\alpha$ LBD was suggested by (1) the strong hybridization signal obtained in ERKO neocortical explants with an oligonucleotide probe specific for the ER- $\alpha$ LBD (Miranda and Toran-Allerand, 1992) (Fig. 6) and (2) ER- $\alpha$-like immunoreactivity in ERKO neocortex, using antibodies to the ER- $\alpha$ LBD (Fig. 7 $A, B$ ) but not with those recognizing the $\mathrm{N}$-terminal region (Fig. $7 D, E$ ). To generate ERKO, the ER- $\alpha$ gene was disrupted by insertion of a $1.8 \mathrm{~kb}$ PGK-Neomycin sequence in the region of exon $2, \sim 280$ bp downstream of the transcription start codon ( $\mathrm{N}$ terminus) (Lubahn et al., 1993), a region far upstream from the LBD (exons $4-8)$. Therefore, ER- $\alpha$-like mRNA found in ERKO neocortex may represent either (1) residual, untranslated ER- $\alpha$ mRNA, (2) a splice variant of ER- $\alpha$, or (3) ER-X mRNA itself. Residual, weak estrogen binding not attributable to ER- $\beta$ has been reported in both ER- $\alpha$ (ERKO) and ER- $\alpha / E R-\beta$ - (double) knock-out adult mouse brains (Shughrue et al., 2002). This binding was identified in ERKO only as a splice variant of ER- $\alpha$ at exon 2 that may regulate the progesterone receptor. Nonetheless, there are compelling reasons to believe that ER-X does not represent the protein product of such a splice variant. A splice variant at exon 2 would contain exactly the same LBD sequence as authentic ER- $\alpha$. However, the ligand specificity of ER-X is clearly different from that of ER- $\alpha$ in that ER-X responds equally well to picomolar concentrations of $17 \alpha$ - and $17 \beta$-estradiol (Fig. $3 a, b$ ). Finally, ER-X simply cannot represent expression of a protein derived from the targeted gene disruption, used to generate
ERKO mice, because ER-X is present at comparable levels in P7 wild-type and ERKO neocortex (Fig. 1b). Earlier studies of cellular variations in ER mRNA translation (Toran-Allerand et al., 1992) have provided data consistent with the hypothesis that some of the ER- $\alpha$-like mRNA detected by in situ hybridization may actually represent ER-X mRNA. Although estrogen binding and ER mRNA expression always colocalized, neurons expressing ER mRNA did not always exhibit nuclear binding, and there was no clear-cut relationship between the widespread hybridization signal (Miranda and Toran-Allerand, 1992) and the limited extent of estrogen binding (Gerlach et al., 1983); evidence of ER-X mRNA?

Our data do not prove that the $\sim 62-63 \mathrm{kDa}$ ER- $\alpha-$ immunoreactive protein binds estrogen. The SDS-PAGE conditions required to separate the $\sim 62-63 \mathrm{kDa}$ protein are incompatible with retention of binding site integrity. Nevertheless, circumstantial evidence suggests that the $\sim 62-63 \mathrm{kDa}$ protein binds estradiol and, moreover, that this binding reaction may mediate activation of ERK1/2. The $\sim 62-63 \mathrm{kDa}$ band and the estradiol binding site are both present in P7 ERKO neocortical membranes that contain neither ER- $\alpha$ nor ER- $\beta$. In ERKO mouse neocortex, $17 \alpha$ - and $17 \beta$-estradiol both activate ERK1/2: both also compete strongly for membrane binding of ${ }^{3} \mathrm{H}$-estradiol (Fig. 8). Levels of membrane binding are similar in ERKO and wild type neocortex, consistent with the observation that similar concentrations of the $\sim 62-63 \mathrm{kDa}$-immunoreactive band are present in membranes from ERKO and wild-type P7 mice (Fig. 1). Finally, progesterone, which does not bind intranuclear ER- $\alpha$ or ER- $\beta$ but does activate ERK in developing brain (Singh, 2001), is capable of competing with ${ }^{3} \mathrm{H}$-estradiol for the membrane binding site, albeit less effectively than $17 \alpha$ - and $17 \beta$-estradiol.

ER-X expression is developmentally regulated in both neocortex and uterus and is maximally expressed at $\sim \mathrm{P} 7-\mathrm{P} 10$. Wild-type and ERKO neocortical and uterine ER-X levels declined during the first postnatal month and became dramatically reduced in the adult, which expressed little ER-X (Fig. 9a,b). Transient, neocortical expression of ER-X mimics the developmental pattern of estrogen binding (Gerlach et al., 1983). That an ER other than ER- $\alpha$ may have developmental importance is even suggested by the original ERKO paper (Lubahn et al., 1993). Because loss of functional ER- $\alpha$ did not appear to influence prenatal sexual development, the authors concluded that development of the reproductive tract can occur in the absence of ER-mediated responsiveness. An alternate explanation is that early development may depend on another ER, such as ER-X.

Developmentally regulated estrogen receptors may be upregulated and re-expressed in the adult brain. Previous studies have demonstrated that $17 \alpha$ - and $17 \beta$-estradiol protect against ischemic CNS injury, as well as neuronal cell death induced by exposure to peroxides or $\beta$-amyloid (for review, see Green and Simpkins, 2000). The neuroprotective efficacy of $17 \alpha$-estradiol has been interpreted as evidence of a direct antioxidant, as opposed to an ER-dependent, mechanism (Behl et al., 1997; Green et al., 1997). Our results suggest an alternative explanation: responses to $17 \alpha$-estradiol may, in part, reflect activation of membrane ER-X response pathways. Developmentally regulated ERs, such as neocortical ER- $\alpha$ and ER-X, latent in the brain since development, may be re-expressed in the adult after injury caused by ischemia, loss of trophic support, or steroid deprivation. ER-X and its signaling pathways could therefore underlie not only the differentiative effects of estrogen in the developing brain but some 
of its neuroprotective actions in the adult (Simpkins et al., 1997; Dubal et al., 1998; Green and Simpkins, 2000).

Proof that ER-X is a novel ER must await sequencing of the protein, currently in progress. The data presented here, however, suggest that this protein is functional and is associated with estradiol-induced activation of the MAPK cascade. Our data further suggest that responses to estrogen during development and after injury are not necessarily mediated via either ER- $\alpha$ or ER- $\beta$. Association with CLMs positions ER-X uniquely to interact with colocalized signaling kinases, providing a novel mechanism for mediation of the influences of estrogen on neuronal differentiation (Toran-Allerand, 1976), survival (Garcia-Segura et al., 2001), and plasticity (Matsumoto and Arai, 1981).

\section{REFERENCES}

Anderson RG (1998) The caveolae membrane system. Annu Rev Biochem 67:199-225.

Anuradha P, Khan SM, Karthikeyan N, Thampan RV (1994) The nonactivated estrogen receptor (naER) of the goat uterus is a tyrosine kinase. Arch Biochem Biophys 309:195-204.

Beato M, Klug J (2000) Steroid hormone receptors: an update. Hum Reprod Update 6:225-236.

Behl C, Skutella T, Lezoualc'h F, Post A, Widmann M, Newton J, Holsboer F (1997) Neuroprotection against oxidative stress by estrogens: structure-activity relationship. Mol Pharmacol 51:535-541.

Bickel PE, Scherer PE, Schnitzer JE, Oh P, Lisanti MP, Lodish HF (1997) Flotillin and epidermal surface antigen define a new family of caveolae-associated integral membrane proteins. J Biol Chem 272:13793-13802.

Blaustein JD (1992) Cytoplasmic estrogen receptors in rat brain: immunocytochemical evidence using three antibodies with distinct epitopes. Endocrinology 131:1336-1342.

Chiaia N, Foy M, Teyler TJ (1983) The hamster hippocampal slice. II. Neuroendocrine modulation. Behav Neurosci 97:839-843.

Das SK, Taylor JA, Korach KS, Paria BC, Dey SK, Lubahn DB (1997) Estrogenic responses in estrogen receptor- $\alpha$ deficient mice reveal a distinct estrogen signaling pathway. Proc Natl Acad Sci USA 94:12786-12791.

Dubal DB, Kashon ML, Pettigrew LC, Ren JM, Finklestein SP, Rau SW, Wise PM (1998) Estradiol protects against ischemic injury. J Cereb Blood Flow Metab 18:1253-1258.

Dubal DB, Zhu H, Yu J, Rau SW, Shughrue PJ, Merchenthaler I, Kindy MS, Wise PM (2001) Estrogen receptor $\alpha$, not $\beta$, is a critical link in estradiol-mediated protection against brain injury. Proc Natl Acad Sci USA 98:1952-19577.

Filardo EJ, Quinn JA, Bland KI, Frackelton Jr AR (2000) Estrogeninduced activation of Erk-1 and Erk-2 requires the G protein-coupled receptor homologue, GPR30, and occurs via trans-activation of the epidermal growth factor receptor through release of HB-EGF. Mol Endocrinol 14:1649-1660.

Fitzpatrick SL, Funkhouser JM, Sindoni DM, Stevis PE, Deecher DC, Bapat AR, Merchenthaler I, Frail DE (1999) Expression of estrogen receptor- $\beta$ protein in rodent ovary. Endocrinology 140:2581-2591.

Friend KE, Resnick EM, Ang LW, Shupnik MA (1997) Specific modulation of estrogen receptor mRNA isoforms in rat pituitary throughout the estrous cycle and in response to steroid hormones. Mol Cell Endocrinol 131:147-155.

Garcia-Segura LM, Olmos G, Tranque P, Naftolin F (1987) Rapid effects of gonadal steroids upon hypothalamic neuronal membrane ultrastructure. J Steroid Biochem 27:615-623.

Garcia-Segura LM, Azcoitia I, DonCarlos LL (2001) Neuroprotection by estradiol. Prog Neurobiol 63:29-60.

Gerlach J, McEwen BS, Toran-Allerand CD, Friedman WJ (1983) Perinatal development of estrogen receptors in mouse brain assessed by radioautography, nuclear isolation and receptor assay. Dev Brain Res 11:7-18.

Green PS, Simpkins JW (2000) Neuroprotective effects of estrogens: potential mechanisms of action. Int J Dev Neurosci 18:347-358.

Green PS, Bishop J, Simpkins JW 1 (1997) 17 $\alpha$-estradiol exerts neuroprotective effects on SK-N-SH cells. J Neurosci 17:511-515.

Gu Q, Korach KS, Moss RL (1999) Rapid action of $17 \beta$-estradiol on kainate-induced currents in hippocampal neurons lacking intracellular estrogen receptors. Endocrinology 140:660-666.

Hajek RA, Robertson AD, Johnston DA, Van NT, Tcholakian RK, Wagner LA, Conti CJ, Meistrich ML, Contreras N, Edwards CL, Jones LA (1997) During development, $17 \alpha$-estradiol is a potent estrogen and carcinogen. Environ Health Perspect [Suppl 3] 105:577-581.

Hawkins MB, Thornton JW, Crews D, Skipper JK, Dotte A, Thomas P (2000) Identification of a third distinct estrogen receptor and reclassi- fication of estrogen receptors in teleosts. Proc Natl Acad Sci USA 97:10751-10756.

Huang CS, Zhou J, Feng AK, Lynch C, Klumperman J, DeArmond SJ, Mobley WC (1999) Nerve growth factor signaling in caveolae-like domains at the plasma membrane. J Biol Chem 274:36707-36714.

Huang J, Choudhri TF, Winfree CJ, McTaggart RA, Kiss S, Mocco J, Kim LJ, Protopsaltis TS, Zhang Y, Pinsky DJ, Connolly ES Jr (2000) Postischemic cerebrovascular E-selectin expression mediates tissue injury in murine stroke. Stroke 31:3047-3053.

Iwabuchi K, Handa K, Hakomori S (2000) Separation of glycosphingolipid-enriched microdomains from caveolar membrane characterized by presence of caveolin. Methods Enzymol 312:488-494.

Kelly MJ, Wagner EJ (1999) Estrogen modulation of G-protein-coupled receptors. Trends Endocrinol Metab 10:369-374.

Kelly MJ, Moss RL, Dudley CA (1978) The effect of ovariectomy on the responsiveness of preoptic-septal neurons to microelectrophoresed estrogen. Neuroendocrinology 25:204-211.

Kuiper GG, Enmark E, Pelto-Huikko M, Nilsson S, Gustafsson JA (1996) Cloning of a novel receptor expressed in rat prostate and ovary. Proc Natl Acad Sci USA 93:5925-5930.

Kuiper GG, Carlsson B, Grandien K, Enmark E, Haggblad J, Nilsson S, Gustafsson JA (1997) Comparison of the ligand binding specificity and transcript tissue distribution of estrogen receptors $\alpha$ and $\beta$. Endocrinology 138:863-870.

Landers JP, Spelsberg TC (1992) New concepts in steroid hormone action: transcription factors, proto-oncogenes and the cascade model for steroid regulation of gene expression. Crit Rev Eukaryot Gene Expr 2:19-63.

Levin ER (2002) Cellular functions of plasma membrane estrogen receptors. Steroids 67:471-475.

Liu P, Ying Y-S, Anderson RGW (1997) Platelet-derived growth factor activates mitogen-activated protein kinase in isolated caveolae. Proc Natl Acad Sci USA 94:13666-13670.

Lubahn DB, Moyer JS, Golding TS, Couse JF, Korach KS, Smithies O (1993) Alteration of reproductive function but not prenatal sexual development after insertional disruption of the mouse estrogen receptor gene. Proc Natl Acad Sci USA 90:1162-1166.

Matsumoto A, Arai Y (1981) Neuronal plasticity in the deafferented hypothalamic arcuate nucleus of adult female rats and its enhancement by treatment with estrogen. J Comp Neurol 197:197-205.

McGookey DJ, Fagerberg K, Anderson RG (1983) Filipin-cholesterol complexes form in uncoated vesicle membrane derived from coated vesicles during receptor-mediated endocytosis of low density lipoprotein. J Cell Biol 96:1273-1278.

Migliaccio A, Pagano M, Auricchio F (1993) Immediate and transient stimulation of protein tyrosine phosphorylation by estradiol in MCF-7 cells. Oncogene 8:2183-2191.

Milner TA, McEwen BS, Hayashi S, Li CJ, Reagan LP, Alves SE (2001) Ultrastructural evidence that hippocampal $\alpha$ estrogen receptors are located at extranuclear sites. J Comp Neurol 429:355-371.

Miranda RC, Toran-Allerand CD (1992) Developmental expression of estrogen receptor mRNA in the rat cerebral cortex: a non-isotopic in situ hybridization histochemistry study. Cereb Cortex 2:1-15.

Nadal A, Ropero AB, Laribi O, Maillet M, Fuentes E, Soria B (2000) Nongenomic actions of estrogens and xenoestrogens by binding at a plasma membrane receptor unrelated to estrogen receptor $\alpha$ and estrogen receptor $\beta$. Proc Natl Acad Sci USA 97:11603-11608.

Nethrapalli IS, Singh M, Guan X, Guo QF, Lubahn DB, Korach KS, Toran-Allerand CD (2001) Estrogen elicits Src phosphorylation in mouse neocortical explants: an upstream event in estrogen activation of the MAP kinase cascade? Endocrinology 142:5145-5148.

Okamoto T, Schlegel A, Scherer PE, Lisanti MP (1998) Caveolins, a family of scaffolding proteins for organizing "pre-assembled signaling complexes" at the plasma membrane. J Biol Chem 273:5419-5422.

Petersen DN, Tkalcevic GT, Koza-Taylor PH, Turi TG, Brown TA (1998) Identification of estrogen receptor $\beta 2$, a functional variant of estrogen receptor $\beta$ expressed in normal rat tissues. Endocrinology 139:1082-1092.

Pietras RJ, Szego CM (1977) Specific binding sites for oestrogen at the outer surfaces of isolated endometrial cells. Nature 265:69-72.

Razandi M, Pedram A, Greene GL, Levin ER (1999) Cell membrane and nuclear estrogen receptors (ERs) originate from a single transcript: studies of $\mathrm{ER} \alpha$ and $\mathrm{ER} \beta$ expressed in Chinese hamster ovary cells. Mol Endocrinol 13:307-319.

Razandi M, Oh P, Pedram A, Schnitzer J, Levin ER (2002) ERs associate with and regulate the production of caveolin: implications for signaling and cellular actions. Mol Endocrinol 16:100-115.

Ros-Baro A, Lopez-Iglesias C, Peiro S, Bellido D, Palacin M, Zorzano A, Camps M (2001) Lipid rafts are required for GLUT4 internalization in adipose cells. Proc Natl Acad Sci USA 98:12050-12055.

Rothberg KG, Ying YS, Kamen BA, Anderson RG (1990) Cholesterol controls the clustering of the glycophospholipid-anchored membrane receptor for 5-methyltetrahydrofolate. J Cell Biol 111:2931-2938.

Schreihofer DA, Resnick EM, Soh AY, Shupnik MA (1999) Transcriptional regulation by a naturally occurring truncated rat estrogen recep- 
tor (ER), truncated ER product-1 (TERP-1). Mol Endocrinol 13:320-329.

Sétáló Jr G, Singh M, Guan X, Toran-Allerand CD (2001) Cellular localization of estradiol-induced phospho-ERK1/2 in mouse cerebral cortical explants: the roles of heat shock protein 90 and MEK2. J Neurobiol 50:1-12.

Shughrue PJ, Stumpf WE, MacLusky NJ, Zielinski JE, Hochberg RB (1990) Developmental changes in estrogen receptors in mouse cerebral cortex between birth and postweaning: studied by autoradiography with $11 \beta$-methoxy-16 $\alpha$-[125I] iodoestradiol. Endocrinology 126:1112-1124.

Shughrue PJ, Lane MV, Merchenthaler I (1997) Comparative distribution of estrogen receptor- $\alpha$ and $-\beta$ mRNA in the rat central nervous system. J Comp Neurol 388:507-525.

Shughrue PJ, Askew GR, Dellovade TL, Merchenthaler I (2002) Estrogen-binding sites and their functional capacity in estrogen receptor double knockout mouse brain. Endocrinology 143:1643-1650.

Simpkins JW, Rajakumar G, Zhang YQ, Simpkins CE, Greenwald D, Yu CJ, Bodor N, Day AL (1997) Estrogens may reduce mortality and ischemic damage caused by middle cerebral artery occlusion in the female rat. J Neurosurg 87:724-730.

Singh M (2001) Ovarian hormones elicit phosphorylation of Akt and extracellular-signal regulated kinase in explants of the cerebral cortex. Endocrine 14:407-415.

Singh M, Sétáló Jr G, Guan X, Warren M, Toran-Allerand CD (1999) Estrogen-induced activation of MAP Kinase (ERK) in cerebral cortical explants: convergence of estrogen and neurotrophin signaling pathways. J Neurosci 19:1179-1188.

Singh M, Sétáló Jr G, Guan X, Frail DF, Toran-Allerand CD (2000) Estrogen-induced activation of the MAP kinase cascade in the cerebral cortex of estrogen receptor- $\alpha$ knock-out mice. J Neurosci 20:1694-1700.

Smart EJ, Ying YS, Mineo C, Anderson RG (1995) A detergent-free method for purifying caveolae membrane from tissue culture cells. Proc Natl Acad Sci USA 92:10104-10108.

Stauffer SR, Coletta CJ, Tedesco R, Nishiguchi G, Carlson K, Sun J, Katzenellenbogen BS, Katzenellenbogen JA (2000) Pyrazole ligands: Structure-affinity/activity relationships and estrogen receptor- $\alpha$ selective agonists. J Med Chem 43:4934-4947.
Subtil A, Gaidarov I, Kobylarz K, Lampson MA, Keen JH, McGraw TE (1999) Acute cholesterol depletion inhibits clathrin-coated pit budding. Proc Natl Acad Sci USA 96:6775-6780.

Sukovich DA, Mukherjee R, Benfield PA (1994) A novel, cell-typespecific mechanism for estrogen receptor-mediated gene activation in the absence of an estrogen-responsive element. Mol Cell Biol 14:71347143.

Toran-Allerand CD (1976) Sex steroids and the development of the newborn mouse hypothalamus and preoptic area in vitro: implications for sexual differentiation. Brain Res 106:407-412.

Toran-Allerand CD (1980) Sex steroids and the development of the newborn mouse hypothalamus and preoptic area in vitro: II. Morphological correlates and hormonal specificity. Brain Res 189:413-427.

Toran-Allerand CD (2000) Novel sites and mechanisms of estrogen action in the brain. In: Neuronal and cognitive effects of oestrogens (Novartis Foundation Symposium 230), pp 56-73. Chichester, UK: Wiley.

Toran-Allerand CD, Miranda RC, Hochberg RB, MacLusky NJ (1992) Cellular variations in estrogen receptor mRNA translation in the developing brain: Evidence from combined ${ }^{125}$-I-estrogen autoradiography and non-isotopic in situ hybridization histochemistry. Brain Res 576:25-41.

Toran-Allerand CD, Singh M, Sétáló Jr G (1999) Estrogen action in the brain: New players in an old story. Front Neuroendocrinol 20:97-121.

Watson CS, Norfleet AM, Pappas TC, Gametchu B (1999) Rapid actions of estrogens in $\mathrm{GH} 3 / \mathrm{B} 6$ pituitary tumor cells via a plasma membrane version of estrogen receptor- $\alpha$. Steroids 64:5-13.

Watters JJ, Campbell JS, Cunningham MJ, Krebs EG, Dorsa DM (1997) Rapid membrane effects of steroids in neuroblastoma cells: effects of estrogen on mitogen activated protein kinase signalling cascade and c-fos immediate early gene transcription. Endocrinology 138:4030-4033.

White R, Lees JA, Needham M, Ham J, Parker M (1987) Structural organization and expression of the mouse estrogen receptor. Mol Endocrinol 1:735-744.

Wyckoff MH, Chambliss KL, Mineo C, Yuhanna IS, Mendelsohn ME, Mumby SM, Shaul PW (2001) Plasma membrane estrogen receptors are coupled to endothelial nitric-oxide synthase through $\mathrm{G} \alpha(\mathrm{i})$. J Biol Chem 276:27071-27076. 